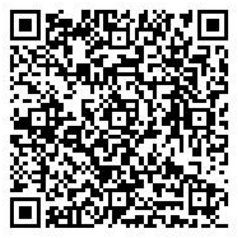

\title{
WOMEN ABUSE: AN ANALYSIS OF CASES AT FAMILY COUNSELLING CENTRE
}

Vranda M.N*, M.Chandrasekhar Rao** \& D. Muralidhar***

\section{Introduction}

Violence against women is a major social concern of every society. UN has listed various forms of violence under the category of gender-based violence abuses such as battering, sexual abuse of female children, dowry-related violence, marital rape and female mutilation. United Nations has defined violence against women as "any act of gender based violence that results in, or likely to result in physical, sexual or psychological harm or suffering to a woman, including threats of such act, coercion or arbitrary deprivations of liberty, whether occurring in public or private life" (UN, 1993). The effect of violence can be devastating to women's

* Vranda M.N, Junior Psychiatric Social Work Consultant, Department of Psychiatric Social Work, NIMHANS, Bangalore - 560 029, E-mail: vrindamn@gmail.com;
Mobile No. : 91-9480380013

** M.Chandrasekhar Rao, Additional Professor Department of Psychiatric Social Work, NIMHANS, Bangalore, India - 560029. *** D. Muralidhar, Professor, Department of Psychiatric Social Work, NIMHANS, Bangalore,
India - 560029 . 
lives. The available literature shows that gender based violence is taking heavy toll on women's lives and causing serious problems. Word Health Organization (1999) reports that violence against women causes more death and disability in the age group of 15 - 44 than cancer, malaria, traffic accidents and war combined. Further UN public information estimates that 1 in every 5 women would face some form of sexual or physical aggression in their lifetime with $20 \%$ to $50 \%$ of the cases being those of domestic violence (UN, 1993). Women are generally abused by men they know (Glezer, 1992; Dwyer et al., 1995). Every year 3 million married women are abused by their partners (Straus, 1998). In India, so far, there is no national level data regarding the extent and magnitude of this problem. Few studies reported that 22 percent to 60 percent of women had experienced violent acts, most commonly at the hands of spouses or relatives (Mahajan, 1990; Rao, 1997).

Women are not only subject to violence by husbands but also from members of natal and the marital home. Girls and women in India are commonly less privileged than boys in terms of their position in the family as well in the society and also their access to material resources and needs. Nevertheless there are regional and community variations. Women in North India have relatively less autonomy than their counterparts in the South, and experience fewer opportunities for control over economic resources (Karve, 1965). Women in the South report fewer beatings that their counterparts in the north (Rao, 1997). Overall domestic violence is prevalent in all settings, regions, and religious groups. However, these variations may be due to difference in reporting of violence.

In India, dowry deaths and wife beating are the major visible violence against married women. Despite the Dowry Prohibition Act of 1961, research indicates 169.7 percent increase in dowry related deaths from the year 1987 to 1991 as well as a 37.5 percent increase in acts of cruelty by husband and relatives during this same period. High level of cruelty against women was reported to be due to dissatisfaction with dowry and the main perpetuators are husband and in-laws (National Crimes Record Bureau, 1995).

Research into the determinants of violence in women remains meagre. The nature, severity and reasons for violence, the needs of such women who seek professional help, reasons for women being in such abusive relationship, and alternatives available to them are yet to be explored in order to plan for proper intervention strategies at the various levels. 


\section{Methodology}

The data for the present study was derived from interviews with 58 women clients who sought help at Family Counselling Centre situated in the premises of Police Commissioner Office at Bangalore. For the present study semi structured interview schedule was designed predominantly with open-ended questions to explore the various issues such as the description of nature of abuse, the socio-demographic characteristic of women and help expected from Counselling centre and future plans of women

\section{Results}

The socio-demographic characteristics of women reveal that majority (84.5\%) of women was in the age group of $15-26$ years. $79.3 \%$ women were from urban background, $72.4 \%$ of sample represents Hindus and $60.3 \%$ of women had less education. Majority (77.6\%) were non-working women. $63.3 \%$ of the women were married and staying with husband whereas remaining 27.6 percent were deserted and 6.9 percent were separated from husband. Most of the women had 4 years of marital life. Nearly half of the sample had no children.

\section{Nature of Problems and Abuse/Violence:}

The majority, 60.3 percent of the women reported dowry related violence, while $32.8 \%$ of women reported violence due to alcohol consumption by their husbands. A relatively small proportion of women (10.3\%) also reported abuse by husband due to his extra marital relationship. $34.5 \%$ of the women have reported problems with duration of less than 20 months. The details of these problems and distress associated with such problems are reported else where by Vranda and Chandrasekhar Rao (2007).

\section{Dowry Related Abuse:}

A persistent demand of dowry by the husband, and in-laws is emerging as a major cause of violence against women. The reason for abuse was mainly due to dissatisfaction with dowry. The women who reported dowry related abuse were subjected to combination of Physical Abuse (in the form of beating with sharp objects, trying to kill by pouring kerosene or attempt to strangle, burning with cigarette or iron rod); Verbal Abuse (i.e., threatening with dangerous consequences, threatening to remarry if the needs are unmet) and Psychological Abuse (in the form of deprivation of food and social contact, constantly throwing her out of the house to bring money and physical isolation in the form of locking inside the 
home). Some of the reasons for demanding money by spouse or in-laws were mainly for meeting personal and economic needs such as to buy a house (34.9\%), to start business $(34.3 \%)$, to buy site/land (1 1.4\%), to construct house $(5.7 \%)$, to drink alcohol (8.8\%) and repayment as a part of unpaid debts or dowry which was promised at the time of marriage (5.7\%). It was found that the amount of dowry given at the time of marriage was ranged between Rs. 35,000/- to Rs. 1, 25,000/. The amount of cash and materials given varied with economic status of the bride's family. Some of the reasons for inability to meet the current demands by the parents are increased debt due to the marriage of the respondent $(77.1 \%)$, money needed for the marriage of other sisters' $(77.1 \%)$, financial difficulties $(65.1 \%)$, and illness in the family members (11.4\%).

\section{Alcohol Related Abuse:}

Excessive alcohol consumption of husband was another reason for violence among these women. These women reported abuse in the forms of Physical Abuse (in the form of beating, kicking, throwing the objects, and forced sex under the influence of alcohol); Verbal Abuse (include use of abusive and filthy language, and threatening to kill); Psychological Abuse (i.e., constantly picking faults, suspiciousness of having extramarital relationship and not allowing to interact with neighbours and other men) and Social Abuse (public humiliation and throwing her out of the house). $42.1 \%$ of women reported that the duration of alcohol consumption by their husbands ranged between 48 - 72 months and $84.2 \%$ had the habit of drinking before marriage.

\section{Abuse due to Husband's Extramarital Relationship:}

The husbands' extramarital affairs caused emotional abuse in the form distancing, decrease in frequency of sexual activity, forcing them to give divorce to end the conjugal relationship, spending no time with children, and not contributing money to maintain the family. Nearly half of the women reported that their refusal to have sex triggered the abuse. It was interesting that half of these women reported they feared to have sexual contact with their husband due to fear of HIV/AIDs.

\section{Help Expected from Family Counselling Centre and Future Plans of Women:}

This section deals with the nature and extent of help expected by the women from the Family Counselling Centre to prevent abusive relationship. The need of the women was in multiple forms. Majority (43\%) of the women wanted police assistance to stop abuse by their husband and in-laws, whereas 33.3\% wanted free legal help to end such abusive relationship. $25 \%$ women expected Counselling or advice to their husband to stop drinking alcohol or extra marital affair. $18.3 \%$ of women 
expected temporary shelter to stay with their children. $16.8 \%$ wanted financial assistance for their children's education.

With regard to the future plans of women $48.3 \%$ of women had no plans, $29 \%$ preferred to die if nothing helps them out, $13.4 \%$ wanted to become independent and secure job and while $10 \%$ preferred to stay with their parents.

\section{Discussion}

This study was intended to explore the reasons and nature of violence and the needs of women who sought the help at a Family Counselling Centre (FCC), Bangalore. The findings of the study clearly demonstrate the presence of various interpersonal causes for abuse/violence among the women seeking help at Family Counselling Centre. Majority of the women who sought the help at FCC were less educated, non-working and were in younger reproductive age. Young age has been identified as a risk factor for domestic violence among women in many studies (Jewkes, 2002, Hoffman, 1994, Ellsberg, 1999, Hofner et al., 2005).

In the current study a persistent demand of dowry by the husband, and in-laws is emerging as a major cause of violence against women. A study on victims of dowry harassment by Kumari (1989) shows that one in every four women were murdered or driven to commit suicide and majority (61.3\%) were thrown out of their husband's home after a long period of harassment and torture. The current study highlighted that these women are subjected to severe forms of cruelty and abuse which are similar to the few Indian studies (Dasgupta, et al., 1984., Gautam and Trivedi, 1989, Thilagaraj et al, 1999). It was also observed that these battered women initially did not report to the police for fear of being harassed by husband and inlaws. Research evidence have shown that majority $72 \%$ of women face violence at the hands of their husbands, and other men in the family whom they know and that too in places they would consider safe (Abuja, 1987). The present findings are in consonance with above findings as such revealed that husband and mother in-law were the major perpetuators of abuse.

Consumption of alcohol was another reason for abuse/violence among these women. An association between use of alcohol by the batterer and violence has been noted in many Indian and Western related studies (Oxford et al, 1976, Parvathi, 1989, Chaudhary, 2000). Further, it found that suspiciousness, infidelity, jealousy and social isolation were related to abuse among these women and the current study also revealed the similar findings (Gayford, 1975; Star, 1980; Hilberman 
and Munson, 1978; Hilberman, 1980). Scott (1974) identified the 'third degree' phenomenon of violence in which alcoholic husband's interrogate their wives for hours until the wives admit some infidelity in order to end argument.

However, compared to other problems, in the present study, women with presence of husband's extramarital affairs reported less physical and social abuse. Emotional abuse was found to be high among the women with this problem. The study brought out some sort of 'emotional divorce' between the couple due to the presence husband's extramarital relationship.

With regard to the help expected from the counsellors the most significant finding of the current study was majority of the women wanted counselors to act as 'mediator' for resolving their problems. The women expected intervention from police to handle their problems. The reason for expecting police assistance could be to prevent the further abuse by husband and other family members. The findings of 176 marital discord cases reported in the family welfare agencies found that it was not so much the economic stress that forced the women to accept any amount of battering but rather the self-image and the pressure of social stigma that allowed the women to tolerate battering for a very long time (Kaushik, 1987).

Moreover, women's faith in marriage as an institution is still strong and majority of the women in the current study still committed to preserve their marriage despite of the odds. This finding directly implies the kind of socio-cultural acceptance and tolerance of abuse/violence. The reasons could be economic dependency, absence of family support, presence of children and social stigma attached to separation. Pagelow (1981) explored three reasons that are considered as explanations for a battered woman not taking any action to get out of a violent situation. First one is 'traditional ideology', which includes the cultural norms and their influence on sexual inequalities. Secondly, 'lack of resources', which includes money, material goods, and support of the family and friends. Lastly, 'institutional responses' which includes the amount and type of support and assistance available and received by the battered women, as well as pressures exerted against women to confine within their martial relationship. The findings of the current study have shown the feelings of 'learned helplessness' among these women. Majority of the women had no plans and preferred death as solution to their problems. The women subjected to prolonged unpredictable and uncontrollable abuse are more likely to have decrease in sense of mastery and self-esteem, which hinder their ability to take active steps to change their situations show sign of learned helplessness which results in severe psychological distress particularly depression (Walker, 1979; Shepherd, 1990). 


\section{Conclusion}

The current study is unique in its nature as it explores the nature of abuse among women seeking help at Family Counselling Centre. It has been found that women who wish to leave abusive marital relationship or seek police protection are faced with number of legal and social service complication such as failure of agency to provide support before separation is obtained, where legal services are extremely slow or unavailable in time of crisis. Remediation of these difficulties by service provider may encourage more women to seek help. The counsellors working in agency should give more priority to the adequate protection and shelter for battered women who wish to leave abusive marital relationship. A significant proportion of women interviewed in the current study stated that their partners had threatened to kill them if their needs are unmet. Though these threats appear to be exaggerations, but women generally perceived it as real situation. Without adequate protection many women consider it futile even to discuss in making changes in their lives. The counselor's decision on the therapy must rest on an assessment of the overall psychosocial functioning, particularly, whether couple's demonstrate sufficient selfcontrol as to preclude further violence. If the relationship is highly volatile, and the woman is fearful of further violence, counselor's attention should be directed at emergency measures such as police assistance, shelters, and legal intervention. It is also necessary that the counselors should have adequate knowledge in risk assessment and wide range of therapeutic modalities. The general goals of therapy in violence cases must include - an immediate cessation of violence, awareness of and intervention in the pattern of escalation of violence by the couple, improve the problem solving abilities of the couples, teaching safety skills especially to women, and expanded marriage contracts. These goals constitute the measures of success in the individual and joint treatment and prevent further marital abuse/violence among women.

\section{References:}

1. Abuja, R. (1987). Crime against women. Jaipur Rawat Publications. New Delhi.

2. Chaudhary, P. (2000). Battered women: A study of domestic violence. Provasha Prakashan,
Bhopal. 3. Dasgupta, et al. (1984). A study on dowry system in West Bengal, Jayaprakas Institute of
Social Change, (Unpublished), Calcutta.

4. Dwyer, D.C., Smokowski, P.R., Bricout, J.C. and Wodarski, J.S. (1995). Domestic violence research: Theoretical and practice implications for social work. Clinical Social Work Journal,
23(2), 185-197. 
5. Ellsberg, M.C., Pena, R., Herrera, A., Liljestrand. J., Winkvist, A.(1999). Wife abuse among women of childbearing age in Nicaragua. American Journal of Public Health. 89, 241-244.

6. Gautam, D.N. and Trivedi, B.N. (1989). Dowry related violence towards women. In S. Sood (Eds). Voilence against women, pp. 293-309 Jaipur: Airhand Publishers.

7. Gayford, J.J. (1975). Wife battering: A preliminary survey of 100 cases; British Medical Journal, 1, $194-197$.

8. Gelles, R.J. (1978). Violence in the American family. In J.P.Martin (Ed). Violence and the Family, pp.169-182 CA: Sage Publication.

9. Glezer, H., Edgar, D. and Prolisko, A. (1992). The importance of family background and early life experiences on premarital cohabitation and marital dissolution, Paper presented 'Family Formation and Dissolution: East and West Perspectives', Taipei, May 1991, ISSP and Sun Yat Sen Institute for Social Science, Academica Sinica.

10. Hilberman, E. and Munson, K. (1978). Sixty battered women. Victimology, 3(3-4), 460-470.

11. Hilberman, E. (1980). Overview: "Wife-beater's wife' reconsidered. American Journal of Psychiatriy, 137(11), 1336-1347.

12. Hoffman, K.L., Demo, D.H., Edwards, J.N. (1994). Physical wife abuse in a non-western society: an integrated theoretical approach. Journal of Marriage Family, 56, 131-146.

13. Hofner, M.C., Python, N.V., Martin. E., Gervasoni, J.P., Graz, B., Yersin, B. (2005). Prevalence of victims of violence admitted to an emergency department. Emergency Medical Journal, $22,481-5$.

14. Jewkes, R., Levin, J., Penn-Kekana, L. (2002). Risk factors for domestic violence: Findings from a South African cross-sectional study. Social Science Medicine, 55, 1603-1617

15. Karve. I. (1965). Kinship Organization in India, Bombay: Asia Publishing House.

16. Kaushik, S. (1987). Social and treatment issues in wife battering - A reconsideration. In S.Sood (Ed), Voilence against women, (pp.23-23), Jaipur: Airhand Publishers.

17. Kumari, R. (1989). Brides are not for burning: Dowry victims in India. Radiant Publishers, New Delhi.

18. Mahajan, A. (1990). Instigators of wife battering. In S. Sood (Eds.). Violence against Women, (pp. 1-10), Jaipur: Airhand Publishers.

19. National Crimes Record Bureau. (1995). Accidental deaths and suicide in India. New Delhi, India.

20. Orford, J., Oppenheimer, E., Egert, S., Hensman, C., and Cuthrie, S. (1976). The cohesiveness of alcoholism and complicated marriages and its influence on treatment outcome. The British Journal of Psychiatry, 128, 318-339.

21. Pagelow M. D. (1981). Women battering victims and their experience. Berverly Hills, CA. Sage Publication.

22. Parvathi,K.(1989). A comparative study on the pattern of violence in familes of alcoholics and non-alcoholics and their family dynamics. Mphil Dissertation (Unpublished), NIMHANS, Bangalore, India. 
23. Rao. V. (1997). Wife beating in rural south India: A Qualitative and econometric analysis. Social Science and Medicine, 44(8), 1169-1180.

24. Scott, P.D. (1974). Battered Wives. The British Journal of Psychiatry, 125, 433-441.

25. Shepherd, J. (1990). Victims of Personal Violence: The Relevance of Symptoms' Model of Psychological Response and Loss-Theory, British Journal of Social Work, 20 (4), 309-332.

26. Star, B. (1980). Patterns of family violence. Social Case Work, 67 (6), 339-346.

27. Straus, M. A. (1983). Ordinary violence, child abuse and wife-beating: what do they have in common? In. D. Finkelhor, R. J.. Gelles, G. T. Hotaling \& M. A. Straus (Eds.). The Darkside of Families: Current Family Violence Research (pp. 213-234). Newbury Park, CA: Sage.

28. Thilagarai, R., Pavithra, M.B., and Rekah, S.S.(1999). Victims of wife battering: A comparative study among working and non-working women. Journal of Social Defense, 48(139), 1-16.

29. United Nations. (1993). Family enrichment: Programs to foster healthy family development, Series No. 8. Geneva

30. Vranda, M.N. and Chandrasekar Rao, M. (2007). Marital problems and psychological distress among women attending family Counselling centre, Indian Journal of Social Psychiatry, 23, 106-112

31. Walker, L.E. (1979). The battered woman, Harper and Row, New York.

32. World Health Organization. (1999). WHO multi-country study of women's health and domestic violence. Geneva. (WHO/EIP/GPE/99.3). 